\title{
THE ARCHIVE PERSONALITY PROTOCOL
}

\section{A great way to resolve a problem.}

\section{BY BRIAN TRENT}

CCT ou can't possibly be drunk, Cynthia! You've been out of cryosleep for less than two hours!"

Cynthia Szabo reluctantly turned her gaze from the ship's viewscreen to regard her inquisitor. "Did you say something?"

Liza Neary's lips curled into a snarl and she was about to retort when the viewscreen flared again. The colony fleet -20 massive Stanford torus vessels launched from Earth 300 years earlier - spread and contracted like a shoal of fish. Little explosions lit the void between them; a macabre light show from humanity's grand attempt at galactic diaspora.

"You look drunk," Liza breathed, bits of cryofrost still dangling from her eyebrows and dreadlocks. "Great. Just great, Cynthia."

"I'm not drunk," Cynthia slurred. "I'm merely rattled, okay? Three centuries of cryosleep, and this is what I wake up to!"

Liza laughed bitterly and squeezed the ends of her dreads. "We knew that the descendants of the original colonists would inevitably form their own societies. Knew that theoretically that might result in conflict, but..."

"How bad is it?"

"Want the laundry list?"

Cynthia nodded reluctantly.

"The Thebes went communist," Liza said, pointing to one of the many silver flecks on the screen. "They've sent a boarding party against the Sparta, which, while we were sleeping, became a loose confederation of libertarian enclaves. The fighting is a messy, level-by-level grudge match now."

"Why isn't the Castor helping? They're the flagship of the entire fleet..."

"Sure, and as the flagship, the Castor was settled by Earth's major entrepreneurial dynasties. Well take a look." Liza tapped the screen and a real-time video bubble opened, displaying a feed of the Castor's agora deck. Sweaty, wearied labourers moved in endless lines, hauling materials through a colourcoded maze of aisles, while uniformed officers monitored them from a cage-walk above.

Liza explained: "In 300 years, the Castor's plutocratic elite formed monopolies on air, water and food supplies, so now they leverage their 'customer base' to gain a fraction of stock advantage against their corporate enemies."

Cynthia burped noisily, earning a scathing glare from her co-councillor. Three centuries! she thought. Seemed like only yesterday that she was climbing into her cryocapsule with the rest of the Emergency Protocol Council,

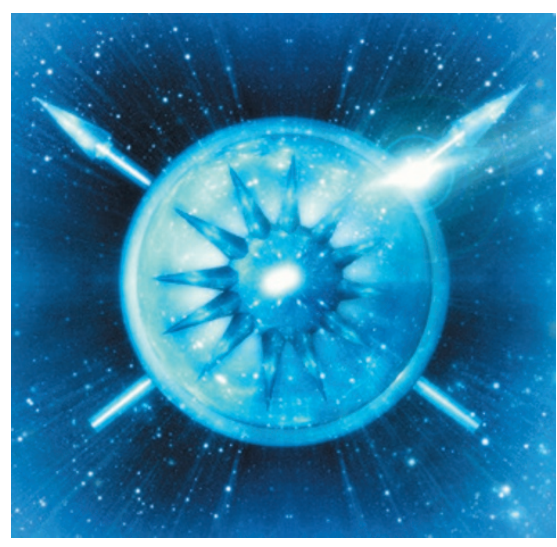

Earth still visible through the porthole. She had expected to sleep the whole way, the cryosleep suspension gas sinking her into a grey and restful slumber until...

She shook herself free of the memory. "Liza, you're not going to tell me the entire fleet has devolved into a free-for-all?"

Liza rubbed her chin. "No, that wouldn't be accurate. We've got two ships that reverted to anarcho-primitivism, with genome clans decrying all technology and raising their kids to believe that their seedships are the entire world. Then there's the Pollux..."

She opened another video bubble. A mass wedding ceremony was taking place. But something was wrong with all the faces...

"One eye is two inches higher than the other," Cynthia gasped. "What the hell?"

"I've been calling them the cubists. Their ancestors apparently decided that asymmetry is the epitome of beauty, so they implemented a merciless breeding programme. The result, over the past three centuries, has been these charming little Picasso people. Anyone born with symmetrical features is ground into mulch."

Cynthia felt sick.

"The rest of the fleet collapsed into oligarchies, despotisms, not one but two feudal states that make sixteenth-century Japan look like Disneyworld, four theocracies, a sopranocracy -"

"Should I even ask?"

"Rule by those with the highest-pitch voices. Sounds like a ship-wide helium leak."

Cynthia couldn't take it anymore. She pulled the hidden flask of vodka from her $\rightarrow$ NATURE.COM

Follow Futures: @NatureFutures f go.nature.com/mtoodm cryosuit pocket and took a mighty swig.

Liza's eyes grew wide. "You are drunk! That explains it!"
“Explains what? That humanity's grand attempt at colonizing the stars has become this free-for-all?"

"Thawed for two hours, and you still found time to get blitzed. Just great, Cynthia."

"Hey, at least I did something! The moment I realized the fleet had degenerated into chaos, I enacted the Archive Personality Protocol!"

Liza started to reply when suddenly two of the ships engaged in hostilities ceased firing. Another pair of ships followed suit.

"As I was saying," Cynthia continued, "the protocol seemed like the only option. It's - "

"A storage of reconstructed personalities, to help us deal with any possible contingency when we reach our destination," Liza snapped. "I know. Benjamin Franklin, Confucius, Saladin, Catherine, Marcus Aurelius ..."

"I decided to use it now, to restore order to the fleet." She trailed off, as more and more ships began to converge into a tight, disciplined formation. The colourful bursts of weapon fire were winking out.

"Ha!" Cynthia exclaimed, the gleam of triumph in her inebriated eyes. "It worked! Good ol' President Hamilton was able to talk sense into everyone!”

Liza stared at her. "President Hamilton?"

"I figured he was the most innocuous, effective choice. He helped to stitch the divided American colonies into a cohesive nation, so..."

Liza checked the archive list of reconstructed personalities. "Alexander Hamilton?" she repeated.

"Yes, goddam it."

"You were drunk," Liza said, shaking her head. "You probably meant to conjure Mr Hamilton, but it looks like your finger slipped and selected the name above his."

Cynthia felt her smile melt. At that moment, a voice erupted from the ceiling speaker. It spoke in a language she didn't recognize.

Liza hit the TRANSLATE option, just in time to catch the tail-end of the message:

"- have failed to lead yourselves, and now I shall lead you. We shall conquer the very stars, world by world, and none shall oppose our unified might! Under my rule, we shall remake the very galaxy! I, Alexander, swear this to you!"

"Alexander?" Cynthia muttered. "The -"

"Great." Liza snatched the flask from her hand and downed a mighty swig. "Just great, Cynthia." -

Brian Trent is a science-fiction writer and traveller. He lives in New England, somewhere between a city and a forest. 